DOI https://doi.org/10.30525/978-9934-26-074-2-70

\title{
ДО ПИТАННЯ ЩОДО ВИЗНАЧЕННЯ МІСЦЯ УХВАЛ СЛІДЧОГО СУДДІ У СИСТЕМІ СУДОВИХ РІШЕНЬ У КРИМІНАЛЬНОМУ ПРОВАДЖЕННІ УКРАЇНИ
}

\author{
Слюсарчук X. P. \\ кандидат юридичних наук, \\ асистент кафедри кримінального процесу та криміналістики \\ Львівського національного університету імені Івана Франка \\ м. Львів, Украӥна
}

Питанню правового регулювання інституту судових рішень у кримінальному провадженні присвячено главу 29 Кримінального процесуального кодексу України (надалі - «КПК України»).

Відтак, аналізуючи ч. 2 ст. 369 КПК України, можемо бачити, що законодавець, виокремлюючи види судових рішень, зазначає: «судове рішення, у якому слідчий суддя, суд вирішує інші питання (які не пов'язані із вирішенням кримінального провадження по суті), викладається у формі ухвали» [1]. На підставі буквального тлумачення цієї норми, можемо стверджувати, що ухвали слідчого судді є судовими рішеннями. Однак, виникає запитання: чи відповідають ухвали слідчого судді у кримінальному провадженні правовій природі судових рішень?

Для початку, не оцінюючи правовий статус ухвал слідчого судді у кримінальному провадженні, варто зазначити, що відповідна законодавча норма викликає зауваження. Зокрема, законодавець іменує ст. 369 КПК України «Види судових рішень». Разом з цим, слід наголосити, що назва цієї статті не відповідає іiі змісту, оскільки аналізуючи норми, які вказані у відповідній статті КПК України, можемо зробити висновок, що законодавець виокремлює не стільки види судових рішень, скільки їхні форми, а саме: вирок, ухвали, постанови. Відповідний висновок можемо зробити ще й тому, що усі рішення у кримінальному провадженні приймаються у «формі», а не у «виді». Форма рішення - це зовнішній вираз (об'єктивізація) рішення у дійсності, своєю чергою, вид рішення це одна 3 одиниць класифікації рішень у кримінальному провадженні. «Вид» рішення $\epsilon$ похідним від «форми» рішення. Тобто, фактично, вид судового рішення $є$ якісно відокремленою формою у відповідності до конкретного критерію класифікації судових рішень у кримінальному провадженні. 
Крім цього, видається недолугою законодавча техніка формулювання ч. 1 ст. 369 КПК України, відповідно до якої: «судове рішення, у якому суд вирішує обвинувачення по суті, викладається у формі вироку», оскільки обвинувачення по суті вирішується судом також і у випадку звільнення особи від кримінальної відповідальності та за наявності підстав для закриття кримінального провадження, своєю чергою, відповідне рішення у кримінальному провадженні приймається у формі ухвали, а не вироку. Відтак, не зрозуміло, чому законодавець обмежив питання вирішення кримінального провадження по суті лише формою вироку.

Повертаючись до визначення правової природи ухвал слідчого судді у кримінальному провадженні та доцільність їх віднесення до судових рішень у контексті тлумачення глави 29 КПК України, принагідно варто наголосити, що первинно ст. 369 КПК України не передбачала слідчого суддю, як суб' єкта прийняття саме судових рішень у кримінальному провадженні. Зокрема, шляхом внесення змін до відповідної статті КПК України лише від «04» жовтня 2019 року законодавець відніс слідчого суддю до суб'єктів прийняття судових рішень у кримінальному провадженні. Такі дії законодавця були логічно пов'язані із низкою не вирішених ним питань щодо визначення правового статусу ухвал слідчого судді у кримінальному провадженні, зокрема: питань, пов'язаних із виконанням відповідних ухвал, можливості їх роз'яснення, виправлення помилок та описок у тексті тощо.

Проте, чи можемо ми стверджувати, що обраний законодавцем «легкий шлях», - банальне віднесення слідчого судді до суб'єктів прийняття саме судових рішень у кримінальному провадженні, вирішив наведені вище проблемні питання правового регулювання? Очевидно, що такий «легкий шлях» не може увінчатись якісним результатом. Більше того, відповідна логіка законодавця спричинила більш глибинні доктринальні дискусії.

Відтак, на підставі тлумачення низки норм КПК України (ст. 21, ст. 24 , ст. 26 , ст. 27 , ст. 110 , ст. 129 , ч. 3 ст. 157 , ст. 164 , ч. 5 ст. 173 , ст. 190 , ст. 196 , ст. 367 , ст. 368 , глава 29 (ст.ст. 369-380); ст. 418, ст. 419), можемо стверджувати, що КПК України послуговується такими поняттями, як:

1) «рішення» у кримінальному провадженні,

2) «процесуальне рішення» у кримінальному провадженні,

3) «рішення судді» у кримінальному провадженні,

4) «судове рішення» у кримінальному провадженні («рішення суду»). 
Відповідний перелік наведений у порядку зростання рішень за обсягом, виходячи із правової природи поняття «рішення», яке може розглядатись у декількох аспектах (значеннях):

1) як внутрішнє переконання суб'єкта, який прийняв рішення,

2) як вольовий акт (внутрішньо-вольова дія) суб'єкта,

3) письмовий акт (документ) - процесуальне рішення.

Досліджуючи питання щодо визначення місця ухвал слідчого судді у системі судових рішень у кримінальному провадженні, крізь призму вищенаведених тверджень, варто зазначити, що законодавець у ст. 369 КПК України ототожнює поняття «рішення судді» та «судові рішення». Проте, відповідний підхід законодавця видається помилковим, оскільки саме поняття «рішення судді» за суб'єктним складом поширюється на слідчого суддю та суд, а поняття «судові рішення» - винятково на суд, що логічно тотожне поняттю «рішення суду» (у контексті визначення поняття «суд», яке надане законодавцем у ст. 3 КПК України).

Разом з цим, слід наголосити, що на відмінність відповідних правових понять вказує низка висновків, які можна отримати на підставі системного тлумачення КПК України, та звісно, керуючись здоровим глуздом, зокрема:

1) видається, що законодавець не спроста розмістив главу 29 КПК України у розділі IV КПК України під назвою «Судове провадження у першій інстанції». Таким чином, за логікою побудови КПК України судові рішення повинні прийматись саме у судовому провадженні (у стадії підготовчого провадження, судового розгляду, апеляційного провадження, касаційного провадження та провадження за нововиявленими обставинами);

2) функції слідчого судді та суду, які ними реалізуються у кримінальному провадженні, $є$ кардинально різними за правовою природою та призначенням відповідних суб'єктів у кримінальному провадженні. Відтак, суд здійснює функцію правосуддя, своєю чергою, на слідчого суддю покладається обов'язок здійснювати судовий контроль за дотриманням прав та свобод людини у стадії досудового розслідування кримінального провадження. Таким чином, правова природа рішень слідчого судді та рішень суду у кримінальному провадженні $є$ різною, ба більше, такою, - що унеможливлює угрупування цих рішень під «єдиний знаменник» - судових рішень у кримінальному провадженні;

3) рішення слідчого судді безумовно є процесуальними рішення, які приймаються у кримінальному провадження. Проте, слід пам'ятати, що не всі рішення, які приймаються суддею у кримінальному провадженні, варто було б вважати судовими рішеннями у контексті «духу» 
глави 29 КПК України (до внесених змін від «04» жовтня 2019 року у ст. 369 КПК України).

Варто наголосити, що безпосереднє врахування фактів, що рішення приймається особою, яка перебуває на посаді судді; що рішення приймається у судовому засіданні; та що рішення приймається у будівлі суду, не можуть автоматично надавати ухвалам слідчого судді статуту «судового рішення» у кримінальному провадженні.

Таким чином, враховуючи усе вищенаведене, можна стверджувати, що обраний законодавцем шлях вирішення проблемних питань щодо правового регулювання ухвал слідчого судді у кримінальному провадженні не відповідає правовій природі інституту судових рішень. Як видається, нагальним питанням є необхідність передбачити у КПК України окрему главу, яка була б присвячена питанням правового регулювання виконання, роз'яснення, внесення змін до ухвал слідчого судді, 3 врахуванням особливостей правового статуту слідчого судді у кримінальному провадженні та покладений на нього функцій.

\title{
Література:
}

1. Кримінальний процесуальний кодекс України: прийнятий 13 квітня 2012 року № 4651-VI. Відомості Верховної Ради України. 2013. № $9-10$, № 11 - 12, № 13. - Ст. 88. http://zakon0.rada.gov.ua/laws/show/ 4651-17

DOI https://doi.org/10.30525/978-9934-26-074-2-71

\section{ВИКОРИСТАННЯ ЗНАНЬ КРИМІНАЛІСТИКИ У ДІЯЛЬНОСТІ ОРГАНІВ ДОСУДОВОГО РОЗСЛІДУВАННЯ І ДІЗНАННЯ У ПРОТИДІЇ ЗЛОЧИННОСТІ}

\author{
Юхно О. О. \\ доктор юридичних наук, професор, \\ завідувач кафедри кримінального прочесу \\ та організачії досудового слідства \\ Харківського національного університету внутрішніх справ \\ м. Харків, Україна
}

Протидія злочинності складається із системи та комплексного впливу на злочинність та окремі ії чинники. Так, А. А. Майоров, визначає, що способи реагування на злочинність можна представити у вигляді системи 